\title{
Do you See What I See? Teaching the Critical Lens of Race in a College Remedial Course
}

\author{
Darlene Russell
}

\begin{abstract}
The ultimate goal of college remedial reading courses are to teach students how to read critically. Teaching students how to read a text usingcritical lenses help to shift their thinking in order to gain a deeper understanding of a text from different perspectives, and to become a better thinker. Students bring their whole self to reading, which includes their multiple identities, cultural background, and worldviews. Teaching students to read through the critical lens of race beckons their whole self and prevailing societal views. The critical lens of race is used to analyze and discuss basic and complex texts. How is the racial lens used to discuss a creative vignette about names? What do students learn about the power of names using the critical lens of race? In reading a vignette about how a girl feels about her name, the connotations of words knotted to racial identity were broached and explored. First-year college students discover truths about others' perceptions by conducting interviews about race and names. Students presented their findings and analysis on the weight of a name through the critical lens of race.
\end{abstract}

Index Terms - College remedial reading, critical lenses, race.

\section{INTRODUCTION}

I landed my first real teaching position when I was in graduate school. It was a part-time English teacher position in the Upward Bound Program. The program was mostly comprised of African-American and Latino students who came from schools all over the city. I was excited to implement the teaching strategies that I was learning. I readied myself for my first class. My lesson plans were set. My copy of the assigned novel was well decorated with annotations, highlights, and neatly folded page corners. Bubbling with anticipation, I scanned my roster to begin recording names in my grade book.

And all of a sudden I was stumped. I read one name and wondered why is this person in the program. The name bellowed a certain ethnicity that did not fit into the demographic scope of Upward Bound. I began thinking about how this student's ethnicity, race or "difference" would play out in the classroom and student exchanges. A few days later I finally met the student and she was not her name. She was a Latina student with a "typical" Middle Eastern last name. Years later, I reflect on this instance and the assumptions I made about a student's ethnicity, race, and even behaviors from her name alone.

In my book, Seeing the invisible: Reading literature through critical lenses, I devote a chapter to names and the inextricable link to identity. The chapter, "A Matter of a

Manuscript received November 8, 2013; revised January 22, 2014.

Darlene Russell is with William Paterson University, USA (e-mail: russelld@wpunj.edu).
Name," includes a poetic vignette, My Name by Sandra Cisneros [1]. This vignette is told from the perspective of a twelve-year old Mexican girl name Esperanza. Esperanza nearly loathes her name because of the potential tie it has to her grandmother's insipid and oppressive life since she was named after her. She also does not like the heavy long sound the letters of her name carries, and the factthat there is no way to really abbreviate her name. Esperanza does share her own glimpse into the power of a name. At her young age, Esperanza is thinking about her name and how it is, at the same time, tied to her heritage and fails to articulate her identity.

My Name was the first literary piece I taught to my first-year college remedial reading class this year. My students ranged in reading comprehensionabilities. According to Tovani [2] many students struggle with reading and understanding what they read because they lack an arsenal of comprehension strategies. In teaching My Name, I paired the vignette with an essay,A Roshanda by Any Other Name [3] in an effort to advance the conversation about names, identity, and perception. These readings were the first pieces that we began to read through the critical lens of race.

\section{CRiticAl Lenses Are CRitical}

It was important to me to design the course using a critical literacy framework. Critical literacy "involves understanding the ways in which language and literacy are used to accomplish social ends". [4] Language and literacy are used to manufacture social constructs surrounding race, class, and gender [5]-[7]. Having taught the college remedial course for a few years, I knew that my students could not just be real readers, but real critical readers. My students were already evaluating occurrences in their lives, in the media, and the news through whatever lenses they were bequeathed or taught to see the world. It was my responsibility to give a name to these lenses, and prime them on the handling of these lenses.

In her work, Appleman [8] makes a case that ideology permeates all kinds of literature. I stressed something very similar to my students. A text - which we broadly defined as a novel, art work, mobile text message and the list goes on - is written from a certain perspective, from a mindset, from a point of view, which is wholly shaped by the writer's experiential knowledge and multiple cultural identities. And critical lenses frame experiential knowledge or ways of knowing and intersections of race, class, and gender.

I explained to my students that reading texts through critical lenses isthe next level of critical thinking. I discussed how the lenses allow the reader to unravel text in ways that would traditionally go unnoticed. "Unravel text is an authentic and deep analysis of the text" [9]. Reading 
literature through critical lenses has the potential to increase social awareness and to react to issues of social justice. Examining a text through critical lenses is inherently political.

The critical lens of race is particularly political, and it was important for me to teach. Critical race lens is used to examine power structures, systems and ideologies as it relates to race [10]. I wanted my students to be able to deconstruct a text with the precision of a conductor of an orchestra at Carnegie Hall. It was also important for me to teach about the race lens given the racial composition of my class (Table I). There were a disproportionate number of students of color. My students ranged from 19-25 years old.

TABLE I: RACE AND GENDER COURSE COMPOSITION $(N=6)$

\begin{tabular}{|l|l|}
\hline Ethnicity & Gender \\
\hline Belizean & Male \\
Hispanic & Male \\
Hispanic & Female \\
African-American & Female \\
Italian & Female \\
\hline
\end{tabular}

\section{FINDING MEANING IN THE NAME CHART}

After reading Cisneros' My Name, I asked students to complete The Name Chart (Table II). Students shared their responses to the chart (Table III). There was a whole class conversation about the meaning of a name, why people are given certain names, and if a name can reveal one's identity. The latter raised much discussion. I remember one student saying that some names are "ghetto" names. I asked her to elaborate. She explained how there are common names in the "hood" and if someone has one of those names, they are from the "hood." She interchanged "ghetto" and "hood". I pointed out how these descriptions and perspectives involve race and class. The etymology of ghetto and the colloquial expression of the "hood" were discussed. I shared my belief that when someone thinks of the "ghetto" they think of a particular group of people with certain hues and behaviors. I explained how the student was looking at names through a critical lens of race. I outlined how the race lens is used in reading a text, having a discussion, and seeing the world.

I shared various stories with the class surrounding the inherent power of a name. I recall my brother telling me that his friend's brother named his son, Diablo, which translates into "devil" in Spanish. My brother elaborated on how the six or seven year old child was misbehaving in school, not listening to his teachers and parents, and really having a difficult time being obedient. I clearly remember my brother concluding that the boy was difficult to manage and acting out because of his name. In my brother's view, the young child was living up to his name. Many students in the class agreed with my brother's position. Some mentioned how the parents were "dumb" and "not thinking" for giving their son such a name. I then posed a rhetoric question: Perhaps, a name really does matter? I extended the conversation by adding how in ancient African civilizations a child's name was carefully chosen, and if the child did not live up to his/her name it would be changed to a name that was fitting of their character and disposition. This name change could occur years after the child was born. I thought about my own situation regarding the naming my daughter. It took me a few days to name her before leaving the hospital. The hospital's official in charge of filing birth certificates called my room a few times to asking if I decided on a name. Each time I requested her to pardon me because I needed more time with my daughter to figure out a name that suited her. This name would be with my daughter for her entire life, I thought, and I had to choose wisely. I knew that her name would be one of the primary identifiers in her journey through life. I was acutely aware that the name I selected could engender negative or unwelcomed perceptions of my daughter. I knew I wanted a unique name that would not easily culturally or racially brand my daughter. I was viewing the blessed occasion of naming my child through a racial lens. To punctuate the discussion about the power of a name, I pointed out to my students how people will correct you if you mispronounce or misspell their name. In fact, some people will become very irate or exasperated when this occurs. Many students nodded in agreement. I then asked the class, do you think a name matters? The class was divided; some believed names mattered while others did not.

Following our discussion, I asked students to quickly place the following names in one of the below columns:

"David, Thyme, Luke, Le-a, Julio, Heather, Tyquan, Kyd, Shanequa, Emma, Maria, Conner, Amina"

TABLE II: THE NAME CHART

\begin{tabular}{|l|l|l|}
\hline$\underline{\text { Athlete }}$ & Business Owner & RecipientWelfare \\
& - & \\
\hline
\end{tabular}

We discussed the unseen text, implications, and perceptions that shaped their responses. I could not help think about the assumptions I made about the racial and ethnic identities of the Upward Bound student I taught years ago after gleaning over the roster. We discussed the realities of cultural norms along ethnic lines along with the static stereotypes that usually accommodate such discourse. Students referenced celebrities and prominent people to defend their answers. One student mentioned how some names on the list are common among African-American people, and the people with these names happen not to have a lot [finances and material possessions] and are on welfare. I highlighted that this very comment is shaped through the critical lens of race. I mentioned the saliency of racial stereotyping in the student's comment. The goal was not necessary for the student, or other students for that matter, to alter their stance as much as it was for the class to see how our perceptions dictate our beliefs. And how the critical lenses of race, class, and gender cradle and nourish our beliefs.

Students charted the names into categories.

The perceptions of names are largely framed around race, and how we are socialized to see the world. I pointed out how a name can influence hiring practices and college admissions, and the sort. This connected to the essay A Roshanda by Any Other Name [3] that students read. Almost every student referenced one of the name stories in the essay stating that it was "terrible" and "insane" what one man did to his two sons. 
He named one "Loser" and the other "Winner." Ironically, "Loser" went on to do well in life while "Winner" failed. This essay moved students to further considered the power of a name.

TABLE III: STUDENTS' RESPONSES

\begin{tabular}{|l|l|l|}
\hline Athlete & Business Owner & $\begin{array}{l}\text { Recipient } \\
\text { Welfare }\end{array}$ \\
David & Connor & Amina Julio \\
Kyd & Emma & Le-a \\
Tyquan & Heather & Maria \\
Thyme & Luke & Shanequa \\
\hline
\end{tabular}

We had similar discussions throughout the course like this where we actively engaged in deconstructing an idea or word. Discussions have the intrinsic power to assist in creating community in the classroom and honoring each person's thoughts and voice [11]. I made a concerted effort to involve students in discussions by personalizing questions as much as possible and drafting their family and friends into the discussion. For example, think of a relative or friend with an "odd" name and what would you do if your parents asking students what would they do if their parents named $t$.

Using the critical lens of race, students were given the mini-research assignment in chapter one called "The Weight of a Name" [9]. They had to find 3-4 people to complete The Name Chartand interview them based on their name categorizing responses. Students had to analyze the findings through a Prezi (creative PowerPoint presentation).

One male student(researcher \#1) interviewed three people - two males and one female - ranging from 17-19 years old (Table IV).

\begin{tabular}{|l|l|l|}
\multicolumn{1}{l}{ TABLE IV: RESEARCHER PARTICIPANTS' RESPONSES } \\
\hline Athlete & Business Owner & $\begin{array}{l}\text { Recipient } \\
\text { Welfare }\end{array}$ \\
Amina & David & Shanequa \\
Thyme & Heather & \\
Tyquan & Connor & \\
Shanequa & & \\
Connor & & \\
\hline
\end{tabular}

When asked to explain their responses to The Name Chart, the participants offered the following:

Female, 17: Black people have names more acceptable to their culture.

People in higher class have names that sound more "fancy." Certain types of names are associated with different cultures.

Male, 18: As a result of media and society, growing up we are seeing all these stereotypes and we are lead to believe different or weird names means something to do with their race or background.

Male, 19: A lot of the time, at least according to my own interpretation, it seems that rather generic and common names are often ascribed to children born of upper-class social elite groups...
My student's conclusion based on his analysis of the readings and research:

After comparing the results of my subject, the article " $A$ Roshanda by Any Other Name" and my own results, it has not been easy to come to a conclusion. Although names are not what make a person, they can give a first impression. Names are sometimes given to people based on racial or economic setting. Other times names are given based on what is and is not acceptable in certain cultures. One does not have to live up to a name or a let a name shape who they are or possibly can be. However despite all of this in today's society a name is one of the first impressions someone gets.

One female student (researcher \#2) interviewed four people ranging in age (Table $\mathrm{V})$.

TABLE V: RESEARCHER PARTICIPANTS' RESPONSES
\begin{tabular}{|l|l|l|}
\hline$\underline{\text { Athlete }}$ & $\begin{array}{l}\text { Business } \\
\text { Owner }\end{array}$ & $\begin{array}{l}\text { Recipient } \\
\text { Welfare }\end{array}$ \\
Heather & Julio & Shanequa \\
Tyquan & Kyd & Maria \\
Connor & Emma & Amina \\
& Le-a & \\
\hline
\end{tabular}

When asked to explain their responses to The Name Chart, the participants offered the following:

Female: People easily get discriminated by their names nowadays.... for example if two people go to an interview for a job and their name is Shanequa and Tyler, we all know who has a better chance to get a call back is the white American name than the African American name. They [prospective employee] think African Americans are lazy and white Americans are hardworking.

Male: I totally hate people who judge people by their names because I was one of them. My name is not common everybody makes fun of it even until now. I always said by name may sound funny but in reality I am who I am, and I am proud of the name I have and I would not change it.

Male: "Never judge a book by its cover." We get discriminated by our names and they don't know who we are...for example just because people have African American names they [other people] already think they are not education, do drugs, and rob people, and that's not right. Some African Americans are really education and some of them really want to succeed in life. I gave this answer because I noticed that African Americans are the most people who get judged easily.

Female: From my point of view I know us people get discriminated by the actions of others and that is because if a Spanish person does something bad every Spanish person will get judged. The same goes for white and African Americans. As soon as they do something they will get judged because of their actions but not everybody is the same... 
My student's conclusion based on her analysis of the readings and research:

No matter what is your name, you are going to be judged/ By reading "A Roshanda by Any Other Name”, I understood that the author is talking about how the move of every parent [regarding the choosing of a name] will greatly influence the child's future and that is completely correct. No matter what is your name you can accomplish anything if you follow the right path and make the right decisions.

The research data of both of my students underscores how people perceive that names are viewed and judged largely through a racial lens. The suggestion of racial identity is mirrored in all of the participants' responses.

\section{CONCLUSION}

I am uncertain whether I gingerly catapulted my students to avoid placing an individual into a racial and social category upon hearing the syllables or twang in a name. I am sure that I invited students to see why they, society, and we make some judgments purely through the critical lens of race alone. One student wrote in his end-of-the-semester reflection: "...Coming into this class I feel as a reader I usually would look in between the lines and try to figure outthe unseen text. After this class, I feel that I honed that skill and am much better at seeing the story from a different lens, and understand the ins and outs of the text..." The only way to see the unseen text is to see it through critical lenses.

\section{REFERENCES}

[1] S. Cisneros, The House on Mango Street, New York, NY: Vintage, 1991.

[2] C. Tovani, I Read it, but I Don't Get it: Comprehension Strategies for Adolescent Readers, Portland, ME: Stenhouse, 2000.
[3] S. D. Levitt and S. J. Dubner. (April 2005). A Roshanda by any other name: How babies with super-black names fare? Slate. [Online]. pp 1-2. Available: http://www.slate.com/articles/business/the_dismal_science/2005/04/a _roshanda_by_any_other_name.html

[4] C. Dozier, P. Johnston, and R. Rogers, Critical Literacy, Critical Teaching: Tools for Preparing Responsive Teachers, New York, NY: Teachers College Press, 2006.

[5] J. V. Diller and J. Moule, Cultural Competence: A Primer for Educators, Belmont, CA: Thomson \& Wadsworth, 2005.

[6] B. Hooks, Yearning: Race, gender, and Cultural Politics, Boston, MA South End Press, 1990.

[7] W. F. Tate et al., "Toward a critical race theory of education," Teachers College Record, vol. 97, pp. 47-68, 1995.

[8] D. Appleman, Critical Encounters in High School English: Teaching Literary Theory to Adolescents, New York, NY: Teachers College Press, 2009.

[9] D. Russell, Seeing the Invisible: Reading Literature through Critical Lenses, Dubuque, Iowa: Kendall Hunt Publishing, 2012.

[10] D. G. Solórzano and T. J. Yosso, "Critical race methodology: Countering-storytelling as an analytical framework for education research," Qualitative Inquiry, vol. 8, pp. 23-44, 2002.

[11] B. Hooks, Teaching Community: Pedagogy of Hope, New York, NY Routledge, 2003.

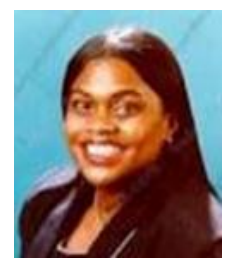

Darlene Russell received a B.A. in English from Hunter College, M.A. in english education, and Ed.D. in college teaching and academic leadership from Teachers College, Columbia University in 1991, 1992, and 2000 respectively in New York, USA.

Currently, she is an associate professor of English Education and Multiculturalism at William Paterson University, Wayne, New Jersey. She is the director of Nurturing Culturally Responsive Equity English Teachers (NCREET), a research project for undergraduate education majors. She is the author of Seeing the Invisible: Reading literature through critical lenses (Dubuque, Iowa: Kendall Hunt).

Dr. Russell is the recipient of the 2009 National Women Educators' Activist Outstanding Curriculum Award from the Research on Women and Education (RWE) Organization. 